Wager, L. R. (1934) Geological investigations in East Greenland. Part 1. General geology from Angmassalik to Kap Dalton. Medd. Grфnland, Bd. 105, Nr. 2

Wager, L. R. and Bailey, E. B. (1953) Basic magma chilled against acid magma. Nature, Lond., Vol. 172, 68-70.

Wager, L. R. and Hamilton, E. I. (1964) Some radiometric rock ages and the problem of the southward continuation of the East Greenland Caledonian orogeny. Nature, Lond., Vol. 204, 1079-1080.

\title{
K/Ar AGE DETERMINATIONS FROM WESTERN GREENLAND
}

\section{Ole Larsen}

(mass spectrometry in collaboration with Jørgen M $\varnothing l l e r$, Fysıske Laboratorium II H.C. Ørsteds Institut, København)

A programme of $\mathrm{K} / \mathrm{Ar}$ age determinations on the rocks of western Greenland from Upernavik $\left(72^{\circ} 50^{\prime} \mathrm{N}\right)$ to Kap Farvel $\left(59^{\circ} 40^{\prime} \mathrm{N}\right)$ has been started and the first results are presented below. The samples used in this first group of resul:s have been selected so that the date obtained would represent the most significant geological event in each area and $\mathrm{s}$ mples from areas in which the geological history is known to be highly complex have been avoided wherever possible. The geological interpretation of the results has been the responsibility of the individual geologists who supplied the samples while the overall geological history outlined in this compilation is that current among members of the Geological Survey of Greenland.

The firs 29 results obtained are listed below together with comments on the geological significance of each date. The figures given re based on preliminary calculations and may be subject to slight ammendments when a full report is published on the work. The error has not yet bcen calculated for most of the determinations; it is assumed to be $\pm 1-3 \%$ unless otherwise noted. 
The K/Ar ages of Precambrian rocks from western Greenland may be divided into groups corresponding to two main periods of plutonic activity at $2700-2500 \mathrm{~m} . \mathrm{y}$. and $1800-1500 \mathrm{~m} . \mathrm{y}$., and one period of cratogenic magmatism at about 1300-1000 m.y. The rocks affected by plutonic activity have been subdivided into three main structural units consisting of two younger fold belts which lie respectively north and south of an earlier basement. Recognisable relics of older basement rocks occur in both the younger fold belts but are not reflected in the $\mathrm{K} / \mathrm{Ar}$ ages given in this paper. The geological boundaries recognised between the three main structural units are situated 1) in the Sфndre Str $\phi$ mfjord area, and 2) north of Ivigtut. The northern of these boundaries, that at S $\phi$ ndre Str $\phi$ mfjord, occurs as an east-west trending zone dividing the Nagssugtoqidian fold belt to the north from the pre-Nagssugtoqidian rocks to the south. A series of basic dykes intruded into the preNagssugtoqidian basement are progressively metamorphosed and broken up as they are followed into the rocks affected by the younger fold belt. The southern boundary, that north of Ivigtut, divides the rocks of the KetilidianSanerutian fold belt to the south from an older, pre-Ketilidian basement. The boundary is clearly seen where supracrustal Ketilidian rocks unconformably overlie older migmatised supracrustal rocks.

The central structural unit of pre-Ketilidian and pre-Nagssugtoqidian rocks stretching from S $\phi$ ndre Str $\phi \mathrm{mfjord}$ to Ivigtut gives two groups of ages, the oldest between $2700 \mathrm{~m} . \mathrm{y}$. and $2300 \mathrm{~m} . \mathrm{y}$., the youngest at about $1800 \mathrm{~m} . \mathrm{y}$. The oldest rocks are found between Godthåbsfjord and Frederikshåb and include the high grade gneisses and metamorphosed anorthosites and pyribolites of the Fiskenæsset area (Windley, this report). The main event dated is thought to be that of the retrograde metamorphism affecting the high grade rocks. A gneiss collected south of the main area of old rocks between Godthåbsfjord and Frederikshåb has given a preliminary result of about $2700 \mathrm{~m} . \mathrm{y}$. The age of this gneiss, which comes from an area just north of the rocks affected by Ketilidian plutonism, supports the idea that the gneisses north of Ivigtut contain elements which were formed contemporaneously with the rocks of the Fiskenæsset area to the north.

The younger group of age determinations from the pre-Ketilidian, pre-Nagssugtoqidian structural unit cannot be related to a major geological event recognised in the field. These dates could represent partial updating of the older rocks by the metamorphism connected to the formation of the two 
younger fold belts (Ketilidian and Nagssugtoqidian), but the regularity with which a figure close to 1800 occurs suggests that they may represent an independent thermal event. The best evidence for the presence of an independent thermal event is found in Godthåbsfjord where McGregor (this report) has recognised a complex history of folding, metamorphism and migmatisation which post-dates a series of basic dykes and which culminates in the emplacement of the Qorqut granite. A pegmatite from this granite gave a date of $1810 \mathrm{~m} \cdot \mathrm{y}$.

The area between S $\phi$ ndre Str $\phi$ mfjord and the inner part of Svartenhuk peninsula gives remarkably consistent $\mathrm{K} / \mathrm{Ar}$ ages of $1690-1770 \mathrm{~m}$. y. The southern part of this area, from Egedesminde to S $\phi$ ndre Str $\phi$ mfjord, belongs to the Nagssugtoqidian fold belt as defined by Ramberg (1949). This fold belt consists mainly of reworked older rocks. The K/Ar ages suggest that the reworking of older rocks south of Egedesminde took place at the same time as the metamorphism of the extensive and well-preserved sedimentary succession of the Karrat Group in the Umanak district (Henderson and Pulvertaft, in press), and that the entire intervening area was influenced by this plutonism.

South of Sermiligârssuk the rocks have all been affected by the Ketilidian and Sanerutian metamorphic events which gave a maximum concentration of ages between 1500 and $1650 \mathrm{~m}$. $\mathrm{y}$. This concentration of ages is more likely to represent the Sanerutian reactivation of the area rather than the main Ketilidian metamorphism which probably occurred slightly earlier in the history of the area. The intrusion of late granites apparently continued until at least $1500 \mathrm{~m} \cdot \mathrm{y}$.

The earliest rocks dated from the Gardar cratogenic magmatic province give a $\mathrm{K} / \mathrm{Ar}$ age of $1275 \mathrm{~m} . \mathrm{y}$. and this must be regarded as the most reliable figure known at present for the beginning of Gardar magmatism. Identical ages of $1220 \mathrm{~m} . \mathrm{y}$. have been obtained from two granitic bodies, on Arsuk Stor $\varnothing$ and at Kinâlik respectively. The age of formation of these granites granites is controversial since on field evidence they are shown to be earlier than the Ivigtut Granite, previously dated at $1255 \mathrm{~m} . \mathrm{y}$. (see the discussion in Bridgwater, 1965, p. 37). The date of $1160 \mathrm{~m} . \mathrm{y}$. obtained on a proved pre-Gardar granite in Kobberminebugt shows that Gardar thermal activity reached far outside the limits observed in the field. The date obtained from Kinalik and on Arsuk Stor $\phi$ could therefore be the result of an extensive heating in Gardar time of originally pre-Gardar rocks. 
Finally a K/Ar age is given for a lamprophyric member of the "trap diabase" swarm of Frederikshåb (Walton, this report). This "T.D." swarm has long been regarded as post-Gardar in age, and the suggestion that it might be Tertiary has been put forward in recent papers. The new K/Ar age determination confirms the post-Gardar age of the dykes and indicates that they are Mesozoic.

\section{References}

Bridgwater, D. (1965) Isotopic age determinations from South Greenland and their geological setting. Medd. Grфnland, Bd.179, Nr. 4.

Henderson, G. and Pulvertaft, T.C.R. (in press) The stratigraphy and structure of the Precambrian rocks of the Umanak area, West Greenland. Medd. dansk geol. Foren.

Ramberg, H. (1949) On the petrogenesis of the gneiss complexes between Sukkertoppen and Christianshaab, West-Greenland. Preliminary report. Medd. dansk geol. Foren., Bd.11, [for 1948] 312-327. 


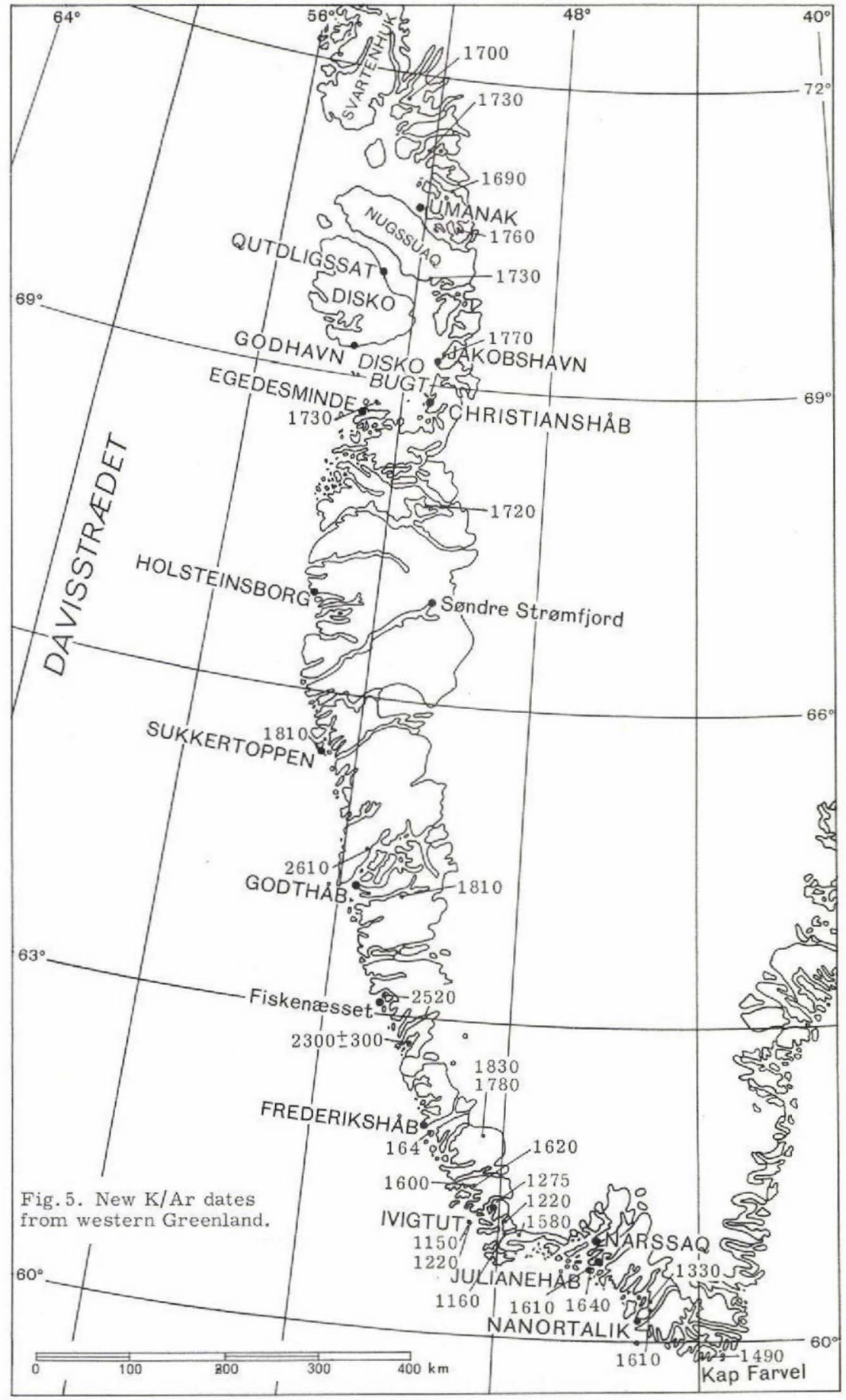


$\mathrm{K} / \mathrm{Ar}$ ages obtained on rocks from western Greenland

Rocks from central West Greenland

$$
2610 \mathrm{~m} . \mathrm{y} \text {. biotite }
$$

GGU 89760, Ipernat dome, Godthåbsfjord area.

Purple leucocratic biotite gneiss formed by the retrogression of granulite facies rocks.

$2520 \mathrm{~m} \cdot \mathrm{y} \cdot$ biotite

GGU 68648, Fiskenæsset.

66-1

Biotite-hypersthene gneiss from the Fiskenæsset area. The date is thought to reflect the retrograde metamorphism of the area.

\section{$2300 \pm 300 \mathrm{~m} . \mathrm{y}$. hornblende}

GGU 74411, immediately north of Frederikshåb glacier.

66-7

Hornblende-bearing metavolcanic rock in greenschist facies. This rock shows no sign of having passed through a higher metamorphic grade than greenschist facies. The age of the formation of these supracrustal rocks relative to the formation of the high grade rocks of the Fiskenæsset area further north is not known. The large uncertainty in the date is due to an abnormally low potassium content.

\section{$1830 \mathrm{~m} \cdot \mathrm{y} \cdot$ biotite}

GGU 73217, south-east of Sermilik fjord, Frederikshåb district. 66-18 For discussion see sample 75199 below.

\section{$1780 \mathrm{~m} . \mathrm{y}$. biotite}

GGU 75199, same locality as 73217 .

Two samples (73217 and 75199) of pre-Ketilidian pelitic metasediments forming micaceous layers in the gneisses, separated by $20 \mathrm{~km}$. It is thought that the two layers may represent the same original lithological unit. The rocks are garnet-bearing mica schists in either high greenschist facies or low amphibolite facies. A preliminary determination on a gneiss from the Frederikshåb district gave an age of approximately $2700 \mathrm{~m}$. y. This shows that the rocks in the Frederikshåb district have been affected by at least 
two thermal events. It is possible that some of the relics of supracrustal rocks belong to a period of sedimentation younger than the formation of the oldest gneiss in the area.

$1810 \mathrm{~m} \cdot \mathrm{y}$. biotite

GGU 89607, Sukkertoppen town.

$66-22$

Biotite-rich hypersthene gneiss. This high grade rock was regarded in the field as a probable northward continuation of the $2500 \mathrm{~m}$. y. belt of high grade gneisses found to the south of Godthåbsford. The comparatively young date obtained suggests that there might be a second group of high grade rocks in this part of West Greenland.

$1810 \mathrm{~m} \cdot \mathrm{y}$. biotite

GGU 79633, Ameralik fjord, Godthåbs district. $66-6$ A pegmatite cutting the Qorqut granite and believed to be closely related to this body.

Rocks of the northern West Greenland fold belt

$1770 \mathrm{~m} \cdot \mathrm{y}$. biotite

GGU 68201, Jacobshavn.

Biotite gneiss from the Jacobshavn gneiss which forms a large area between the northern limit of Ramberg's mapping of the Nagssugtoqidian and the southernmost limit of gneisses which can reasonably be equated with the Umanak gneiss (see 66-12 below).

$1760 \mathrm{~m} \cdot \mathrm{y}$. biotite

GGU 83613, Drygalskis Halv $\varnothing$, Umanak district.

$66-12$

Biotite-hornblende gneiss from the Umanak gneiss which is believed to have formed the basement on which the Karrat Group was deposited. The K/Ar date shows that this gneiss was updated by the metamorphism which affected the younger group of sediments.

$1730 \mathrm{~m} \cdot \mathrm{y}$. biotite

GGU 49903, Kangerdluarssuk, Umanak district. $66-11$

Biotite semipelite (metagreywacke) from the upper formation in the Karrat Group. 
$1730 \mathrm{~m} . \mathrm{y}$. biotite

GGU 68326, east of Sarqaq, Nagssuaq peninsula.

66-13

Biotite gneiss belonging to the same complex as 83613 .

$1730 \mathrm{~m} \cdot \mathrm{y}$. biotite

GGU 36052, easternmost island in the Eqûtit skerries,

$66-15$

Egedesminde district.

Staurolite-biotite schist from a supracrustal group. The time of deposition of this group relative to the formation of the gneisses of the Nagssugtoqidian fold belt to the south is not known; however the latest metamorphism to affect these rocks occurred at the same time as the metamorphism of the Karrat Group to the north.

$1720 \mathrm{~m} \cdot \mathrm{y}$. biotite

GGU 83535, Nordre Str $\phi$ mfjord.

Biotite gneiss from the Nagssugtoqidian fold belt of Ramberg (1949).

$1700 \mathrm{~m} \cdot \mathrm{y}$. biotite

GGU 24579, Ingia fjord, Umanak district. $66-10$ Biotite-garnet schist from the lower formation in the Karrat Group. This is at present the northernmost sample dated from West Greenland.

\section{$1690 \mathrm{~m} \cdot \mathrm{y}$. biotite}

GGU 24407, Nunârssugssuaq, Umanak district. 64-3

Pegmatite cutting Umanak gneiss. See the comment on 66-12.

Rocks affected by the metamorphism associated with the formation of the Ketilidian - Sanerutian fold belt of southern Greenland

$$
1610 \mathrm{~m} \cdot \mathrm{y} \text {. biotite }
$$

GGU 64008, Pårdlit island, close to Julianehåb town. $65-3$

Julianehåb Granite. This granite is cut by metadolerite dykes.

$1640 \mathrm{~m} . \mathrm{y}$. biotite

GGU 64009, same locality as sample 64008 .

$65-1$

Granitic pegmatite cutting a metadolerite dyke. The K/Ar ages of 
64008 and 64009 are both regarded as reflecting the metamorphic effect of the Sanerutian reactivation of the Julianehåb Granite.

$$
1620 \mathrm{~m} \cdot \mathrm{y} \text {. biotite }
$$

GGU 64228, north side of Tigssaluk fjord, Ivigtut district.

Banded biotite gneiss adjacent to a "trap diabase". This sample was collected to try to date the time of intrusion of the dyke but the thermal effect of the dolerite appears to have been negligable as the date is the same as the surrounding gneiss (65-21 below).

$$
1600 \mathrm{~m} \cdot \mathrm{y} \text {. biotite }
$$

GGU 64232, same locality as sample 64228 .

Conformable granitic pegmatite in gneiss. The age given by these rocks is that of the Sanerutian metamorphism in the area although the gneiss is known to be pre-Ketilidian.

$1610 \mathrm{~m} \cdot \mathrm{y}$. biotite

GGU 51654, Nanortalik peninsula

Semipelitic migmatite belonging to the Tasermiut fjord supracrustal succession. The $1610 \mathrm{~m} . \mathrm{y}$. date is that of the Sanerutian metamorphism which appears to have affected all the pletonic rocks of South Greenland.

$1580 \mathrm{~m} . \mathrm{y}$. biotite

GGU 61098, western Julianehåb area from the nunatak to the $65-43$ north-east of Isortoq.

A late intrusive granite cutting the Ketilidian migmatites. The age suggests that this is one of the youngest rocks in the Ketilidian-Sanerutian fold belt in this area.

$1490 \mathrm{~m} \cdot \mathrm{y}$. biotite

GGU 77950, Kap Farvel, the southernmost tip of Greenland. $66-14$ A late intrusive granite representing the youngest major plutonic activity in the area. The date shows conclusively that neither the Caledonian nor the Grenville fold belts pass through South Greenland. 
$1330 \mathrm{~m} \cdot \mathrm{y}$. phlogopite

GGU 24147, Sarqâ, Nanortalik area. 65-2 Ultrabasic body of appinitic affinities. This is the youngest date obtained from a plutonic rock in South Greenland. However it is possible that the formation of the phlogopite post-dates the intrusion of the body.

Cratogenic magmatic rocks of the Gardar period and earlier rocks affected by the emplacement of Gardar intrusions

$$
1275 \mathrm{~m} . \mathrm{y} \text {. biotite }
$$

GGU 23233, south-east side of Arsuk Fjord, Ivigtut area.

A lamprophyre representing the early Gardar activity in the Ivigtut area. Similar dykes cut the Grфnnedal-Íka intrusion.

$1220 \mathrm{~m} \cdot \mathrm{y}$. biotite

GGU 39060, Kînalik, south-east Ivigtut area.

65-28

Granite veins from a para-autochthonous granite emplaced into earlier metasediments and augen gneisses. Regarded as a late-Ketilidian granite possibly affected by a Gardar thermal event.

\section{$1220 \mathrm{~m} \cdot \mathrm{y}$. biotite}

GGU 64120, Arsuk Stor $\phi$, Ivigtut district.

Metavolcanic rock taken directly at the contact of the Arsuk Stor $\varnothing$ Granite. Thought to have been affected by a thermal event latter than the intrusion of the Arsuk Stor $\varnothing$ Granite, see 65-28 above.

$$
1150 \mathrm{~m} \cdot \mathrm{y} \text {. biotite }
$$

GGU 64168, Arsuk Stor $\phi$, Ivigtut district.

Biotite granite (see 65-23 above). The biotite in this rock is intergrown with chlorite and the date obtained must be regarded as a minimum.

$$
1160 \mathrm{~m} \cdot \mathrm{y} \text {. biotite }
$$

GGU 64145, island in the inner part of Kobberminebugt. 65-22 A typical late Ketilidian granite, updated by the effect of the late Gardar magmatism. 
Phanerozoic igneous rocks

$164 \mathrm{~m} \cdot \mathrm{y}$. biotite

GGU 64241, from the large island $5 \mathrm{~km}$ south of $66-16$ Frederikshåb town.

A biotite-bearing lamprophyric member of the "trap diabase" suite. 